\section{Recombinant human arginase I immobilized on gold and silver nanoparticles: preparation and properties}

\author{
Natalia Stasyuk, ${ }^{1,2}$ Roman Serkiz, ${ }^{2}$ \\ Stepan Mudry, ${ }^{2}$ Galina Gayda, ${ }^{1}$ \\ Andriy Zakalskiy, ${ }^{1}$ Yevgen Koval'chuk, ${ }^{2}$ \\ Mykhailo Gonchar, ${ }^{1,3}$ Marina Nisnevitch ${ }^{4}$ \\ ${ }^{1}$ Institute of Cell Biology, NAS of Ukraine; \\ ${ }^{2}$ Ivan Franko National University of Lviv, \\ Ukraine; ${ }^{3}$ University of Rzeszow, Poland; \\ ${ }^{4}$ Ariel University Center of Samaria, \\ Ariel, Israel
}

\section{Abstract}

Metal nanoparticles (NPs), such as gold $\mathrm{(Au})$ and silver $(\mathrm{Ag})$, are important for chemistry, physics, and biology due to their unique optical, electrical, and photothermal properties. Such NPs are widely used for immobilization of various bioactive substances, including peptides, enzymes, antibodies and DNA. The synthesis of silver and gold nanoparticles was carried out by reduction of silver nitrate by glucose and reduction of tetrachloroauric acid by sodium citrate, respectively. The size and structure of the AgNPs and AuNPs were characterized using TEM, AFM and XRD methods. The average size of the AgNPs and AuNPs was between 8 and $15 \mathrm{~nm}$. Recombinant arginase I was immobilized using the carbodiimidepentafluorophenol method on the surface of NPs functionalized with $\omega$-mercaptohexadecanoic acid. It was shown that recombinant human liver arginase I isolated from the yeast Hansenula polymorpha maintains satisfactory stability after immobilization on both NPs. The immobilized arginase retained $40 \%$ of its activity on the surface of AuNPs and 25\% on AgNPs compared to the free arginase after storage at $+4{ }^{\circ} \mathrm{C}$ during 25 days. The immobilized enzyme can be used for assay of arginine in pharmaceuticals, in food products and in blood.

\section{Introduction}

Metal nanoparticles (NPs), such as gold $\mathrm{Au})$ and silver $(\mathrm{Ag})$, have recognized importance in chemistry, physics, and biology due to their unique optical, electrical, and photothermal properties. ${ }^{1-3}$ Such NPs have potential applications in analytical chemistry and have been used as probes in mass spectroscopy, ${ }^{4}$ as well as in the colorimetric detection of proteins and DNA. ${ }^{5}$ AuNPs have photothermal properties that can be exploited for localized heating which results in drug release, thus increasing their potential for therapeutic applications. ${ }^{6}$ AuNPs and AgNPs also exhibit a unique phenomenon, known as Surface Plasmon Resonance, which is responsible for their large cross-sections for absorption and scattering, which are four to five orders of magnitude larger than those of conventional dyes. Furthermore, their optical properties can be controlled by varying their size, shape and composition.

Various methods for the synthesis of Auand AgNPs have been reported over the last two decades. They involve the reduction of $\mathrm{HAuCl}_{4}$ and $\mathrm{AgNO}_{3}$ with chemical reducing agents such as citric acid, borohydride, or other organic compounds. ${ }^{7,8}$ Metallic NPs have been widely used in the immobilization of many bioactive substances such as peptides, enzymes ${ }^{9}$ and antibodies. ${ }^{10}$ AuNPs are among the most commonly used materials, due to their low toxicity. ${ }^{11}$

Numerous methods have been used for detecting AuNPs, including colorimetric, scanometric, fluorescence, surface-enhanced Raman scattering and electrochemical techniques. AuNPs-based colorimetric assays in particular demonstrate great potential in point-of-care testing assays. ${ }^{12}$

Use of NPs as carriers for immobilized enzymes has the following advantages: i) higher specific surface available for the binding of a larger amount of enzyme; ii) lower mass transfer resistance and less fouling. ${ }^{13}$

Arginase (EC 3.5.3.1; L-arginine amidinohydrolase) is a key enzyme of the urea cycle. It catalyses the final cytosolic reaction of urea formation in the mammalian liver - the conversion of arginine to ornithine and urea. Arginase has recently been considered not only as a prospective pharmaceutical in enzymotherapy of some kinds of cancers auxotrophic for arginine,,$^{14}$ but also as an analytical instrument for L-arginine assay.

The aim of the present study was to immobilize the recombinant human arginase I on AuNPs and AgNPs and to characterize the obtained enzyme-NPs: analyses of their size, structure, enzymatic activity and stability.

\section{Materials and Methods}

Silver nitrate, D-glucose, tetrachloroauric acid trihydrate, sodium citrate, 1-cyclohexyl-3(2-morpholinoethyl) carbodiimide hydrochloride (CMC), pentafluorophenol (PFP), 2-(2aminoethoxy) ethanol (AEE), dimethylformamide (DMF), N,N-diisopropylethylamine (DIPEA), phenylmethylsulfonilfluoride (PMSF) and 16-mercaptohexadecanoic acid (MHDA) were obtained from Sigma-Aldrich (St. Louis, M0, USA).
Correspondence: Marina Nisnevitch, Arie University Center of Samaria, Ariel 40700, Israel. Tel: +972.3-9066607 - Fax: +972.3.9066323.

E-mail:marinan@ariel.ac.il

Key words: silver and gold nanoparticles, recom binant human arginase I, covalent enzyme immobilization, yeast Hansenula polymorpha.

Acknowledgements: this research was supported in part by CRDF grant UKB1-9048-KV-10 and by the Research Authority of the Ariel University Center of Samaria.

Received for publication: 15 June 2011.

Accepted for publication: 7 September 2011.

This work is licensed under a Creative Commons Attribution NonCommercial 3.0 License (CC BYNC 3.0).

(C) Copyright N. Stasyuk et al., 2011

Licensee PAGEPress, Italy

Nanotechnology Development 2011; 1:e3

doi:10.4081/nd.2011.e3

\section{Enzyme preparation}

Human liver arginase I was isolated from the recombinant yeast strain NCYC 495 . pGAP1-HsARG1 (leu2car1 Sc:LEU2) Hansenula polymorpha, constructed in the Institute of Cell Biology, NAS of Ukraine. ${ }^{15}$ Cultivation of the recombinant yeast cells was performed in flasks on a shaker $(200 \mathrm{rpm})$ at $30^{\circ} \mathrm{C}$, for $48 \mathrm{~h}$, in a Burkholder basal medium containing 1 $\mathrm{mM}$ L-arginine and $20 \mathrm{~g} / \mathrm{L}$ sucrose, $3 \mathrm{~g} / \mathrm{L}$ $\left(\mathrm{NH}_{4}\right)_{2} \mathrm{SO}_{4}, 0.5 \mathrm{~g} / \mathrm{L} \mathrm{KH}_{2} \mathrm{PO}_{4}, 0.2 \mathrm{~g} / \mathrm{L} \mathrm{MgSO}_{4}$ and $0.15 \mathrm{~g} / \mathrm{L} \mathrm{CaCl}$. The medium contained $2 \mathrm{ppb}$ biotin, $0.07 \mathrm{ppm} \mathrm{Zn,} 0.2 \mathrm{ppm}$ Fe and $0.01 \mathrm{ppm}$ of trace elements $\mathrm{B}, \mathrm{Cu}, \mathrm{Mn}$ and $\mathrm{Mo}$, added in the form of appropriate salts. To obtain the cell-free extract (CE), washed cells were suspended in $30 \mathrm{mM}$ HEPES buffer, pH 7.5 (HB), containing $1 \mathrm{mM}$ PMSF and $1 \mathrm{mM}$ EDTA, disrupted with glass beads $(\mathrm{d}=0.45-0.5 \mathrm{~mm})$ in a disintegrator at $1000 \mathrm{rpm}(\mathrm{r}=10 \mathrm{~cm})$ at $4^{\circ} \mathrm{C}$ for $6 \mathrm{~min}$ and centrifugated at $20,000 \mathrm{~g}$ for $40 \mathrm{~min}$. The supernatant, CE, was used for enzyme isolation by one-step column chromatography on the synthesized by us affinity sorbent. To obtain this sorbent, controlled pore glass (with pore diameter $3680 \mathrm{~nm}$ ) was activated with $\gamma$ glycidoxypropyltriethoxysilane, and after this L-arginine was coupled to the synthesized glycidyl-containing matrix..$^{15}$ Arginase was eluted by $0.5-2 \mathrm{M} \mathrm{NaCI}$ in $\mathrm{HB}$, fractions with the highest enzyme specific activity were combined and homogeneity of the final arginase preparation was approved by PAAG-SDS electrophoresis. As a result, a 200 -fold purified preparation of recombinant arginase was obtained with $15 \%$ yield. $^{16}$ The enzyme preparation having specific activity of $530 \mathrm{U} / \mathrm{mg}$ of protein was immobilized on NPs. 


\section{Measurements of enzymatic activity}

Arginase activity (for all enzyme preparations - free and immobilized on both NPs) was determined in a two-step reaction: i) enzymatic conversion of L-arginine to ornithine and urea and ii) photometric registration of urea content by the colorimetric method. Arginase specific activity was calculated as the rate of urea production ( $\mu \mathrm{mole} \cdot \mathrm{min}^{-1} \cdot \mathrm{mg}^{-1}$ of protein). Usually, $200 \mu \mathrm{L}$ of a substrate mixture ( $65 \mathrm{mM}$ L-Arg, $2 \mathrm{mM}$ manganese(II) chloride in $20 \mathrm{mM}$ Tris-base solution, $\mathrm{pH}$ 9.5) pre-incubated at $37^{\circ} \mathrm{C}$ was added to the test tube with 10 $\mu \mathrm{L}$ of arginase preparation. The reaction mixture was incubated for $15 \mathrm{~min}$ at $37^{\circ} \mathrm{C}$ followed by urea assay. ${ }^{16}$ To estimate urea content (mM), the commercial kit (SIMKO, Lviv, Ukraine) was applied. The kit is based on a photometric registration of pink-red complex, produced in diacetyl monooxime conversion under acidic $\mathrm{pH}$. After the $1^{\text {st }}$ step of the reaction, aliquots of reaction mixture were immediately distributed into tubes with the $2^{\text {nd }}$ step reaction mixture. After incubation in boiling water during $15 \mathrm{~min}$, the tubes were put in icewater for 5 min and the optical densities of the experimental and standard test samples, containing urea, were measured at $520 \mathrm{~nm}$.

\section{Synthesis of gold nanoparticles}

Gold nanoparticles (AuNPs) were prepared by the citrate reduction method. ${ }^{8} 1.25 \mathrm{~mL}$ of 1 $\mathrm{mM} \mathrm{HAuCl}_{4}$ and $0.125 \mathrm{~mL}$ of $38.8 \mathrm{mM}$ trisodium citrate were mixed at $100^{\circ} \mathrm{C}$ and stirred for 15 min to obtain a wine-red solution. AuNPs were precipitated from the reaction mixture by centrifugation (3000 g; Hettich Micro-22R centrifuge), washed with $0.1 \mathrm{M} \mathrm{NaCl}$ in $0.1 \mathrm{M}$ HEPES buffer, pH 7.5 (HB), water and final AuNPs precipitate was dried $\left(100^{\circ} \mathrm{C}, 24 \mathrm{~h}\right) .5$ mg AuNPs were re-suspended in $1 \mathrm{ml}$ water in order to estimate the concentration. Under the described conditions, a colloid solution of AuNPs in water at a concentration of $5 \mathrm{mg} / \mathrm{mL}$ (25 mM) was obtained for further characterization and enzyme immobilization.

\section{Synthesis of silver nanoparticles}

Silver nanoparticles (AgNPs) were prepared by the glucose reduction method. ${ }^{7} 0.1 \mathrm{~mL}$ of $0.15 \mathrm{M} \mathrm{AgNO}_{3}$ and $25 \mathrm{~mL} 0.03 \mathrm{M} \mathrm{D}$-glucose were mixed and $0.5 \mathrm{~mL} 0.05 \mathrm{M} \mathrm{NaOH}$ was added to the reaction mixture. AgNPs were precipitated by centrifugation (3000 g; Hettich Micro-22R centrifuge). The precipitate was washed with $0.1 \mathrm{M} \mathrm{NaCl}$ in $0.1 \mathrm{M} \mathrm{HB}$, water and final AgNPs precipitate was dried $\left(100^{\circ} \mathrm{C}\right.$, $24 \mathrm{~h}) .15 \mathrm{mg}$ AgNPs were re-suspended in $1 \mathrm{~mL}$ water in order to estimate the concentration. Under the described conditions, a colloid solution of AgNPs in water at a concentration 15 $\mathrm{mg} / \mathrm{mL}$ (138 mM) was obtained for further characterization and enzyme immobilization.

\section{Immobilization of arginase on the gold and silver nanoparticles}

NPs were incubated overnight in $5 \mathrm{mM}$ MHDA in ethanol at $+4^{\circ} \mathrm{C}$. After rinsing with DMF, the MHDA-covered NPs were incubated in a DMF solution of $20 \mathrm{mM} \mathrm{CMC,} 20 \mathrm{mM}$ PFP, and $20 \mathrm{mM}$ DIPEA for $30 \mathrm{~min}$ at $25^{\circ} \mathrm{C}$. After repeated rinsing with DMF, condensation of the activated $\mathrm{Au}$ - and Ag-linked carboxylic groups with amine groups of the enzyme was carried out. $25 \mu \mathrm{L}$ of the enzyme solution in 30 $\mathrm{mM}$ HB was incubated with NPs for $1 \mathrm{~h}$ at $25^{\circ} \mathrm{C}$. After rinsing with $\mathrm{HB}$, blocking of unreacted carboxylic groups with $0.1 \mathrm{M}$ solution of AEE in $0.1 \mathrm{M}$ bicarbonate buffer, $\mathrm{pH} 8.0$, was performed. The bio-functionalized $\mathrm{Au}-$ and AgNPs were rinsed with $\mathrm{HB}$ and stored at $+4^{\circ} \mathrm{C}$ until used.

The amount of immobilized enzyme on the NPs was determined as the difference between the initial and unbound protein content in the immobilization medium using the Lowry protein assay method.

\section{Identification of nano-scale particles}

\section{Powder X-ray diffraction}

X-ray diffraction patterns were obtained using a DRON-3 diffractometer. In order to obtain the more precision data, Brag-Brentano focusing geometry was used. Scattered intensity as a function of scattered angle $2 \theta$ was recorded with high accuracy $(\Delta \theta / \theta=1 \% ; \Delta \mathrm{V}$ $\mathrm{I}=3 \%$ ).

\section{Optical}

The formed AuNPs and AgNPs were characterized by UV-Vis spectroscopy (300-700 nm) on a Shimadzu UV-1650 PC spectrophotometer. The total concentration of the metal in NPs solutions was determined gravimetrically.

\section{Transmission electron microscopy}

NPs analysis was carried out on a film-coated drop using a PEM-100 transmission electron microscope. The special covered film was formed on the copper net (300 mesh) with a Butvar solution B-98 (Sigma, St. Louis, M0, USA) in $1.5 \%$ chloroform using an ultrasound method (USDN-2T at resonance frequency 24 $\mathrm{kHz}$ ) followed by dropping the sample NPs on the surface of the composed film.

\section{Atomic force microscopy}

The size and structure of gold NPs and their complexes with enzyme were studied by atomic force microscope Solver P47-PRO (NTMDT). An aliquot of the tested sample was spread on the surface of freshly-cleaved mica, dried and analyzed in air using the tapping mode with a resonance frequency of $160 \mathrm{kHz}$, scan rate of $1 \mathrm{~Hz} / \mathrm{s}$ and resolution of $256 \times 256$ pixels.
Effect of $\mathrm{pH}$, temperature and storage time on arginase activity

To estimate the $\mathrm{pH}$ optima of arginase activity for free enzyme and immobilized on AuNPs, the substrate mixtures for arginase assay were prepared using different $20 \mathrm{mM}$ buffers: MOPS, pH 4.0; K, Na-phosphate, $\mathrm{pH} 6.0$ and 7.0; HEPES pH 7.5; Tris-HCl, pH 8.8; Na-borate, $\mathrm{pH} 10.5$ and 12.0. The rest of the procedure (pre-incubation, enzymatic and colorimetric reactions) was the same as described in the Measurement of enzymatic activity part.

The effect of temperature was examined for free and immobilized arginase preparations in standard reaction mixture under different temperatures. To estimate the temperature optima, the substrate mixture of the first step of reaction (conversion of arginine to urea) was pre-incubated for $5 \mathrm{~min}$ at $10^{\circ} \mathrm{C}, 23^{\circ} \mathrm{C}$, $37^{\circ} \mathrm{C}, 50^{\circ} \mathrm{C}, 60^{\circ} \mathrm{C}, 70^{\circ} \mathrm{C}, 80^{\circ} \mathrm{C}, 90^{\circ} \mathrm{C}$ or $100^{\circ} \mathrm{C}$ and incubated with enzyme for $7 \mathrm{~min}$ at the same temperature. The second step of the reaction (urea registration) was done at the standard conditions. To estimate arginase thermostability, the tested samples were pre-incubated for $15 \mathrm{~min}$ at the different temperatures $\left(10^{\circ} \mathrm{C}\right.$, $23^{\circ} \mathrm{C}, 37^{\circ} \mathrm{C}, 50^{\circ} \mathrm{C}, 60^{\circ} \mathrm{C}, 70^{\circ} \mathrm{C}, 80^{\circ} \mathrm{C}, 90^{\circ} \mathrm{C}$ and $100^{\circ} \mathrm{C}$ ) and cooled by ice water. Then the standard test for enzyme activity determination was carried out.

Stability test of enzyme preparations (free or immobilized on NPs) in terms of repetitive applications was performed in three successive measurements during the day. For examination of storage stability, the enzyme preparations were kept at $+8^{\circ} \mathrm{C}$ in $\mathrm{HB}$ and the samples were tested during several days.

The results were obtained from at least three independent experiments. The highest value of arginase activity in each set was assigned as $100 \%$ activity.

\section{Results}

\section{Powder X-ray diffraction}

XRD pattern of the AuNPs is shown in Figure 1. All diffraction peaks, including not only the peak positions, but also their relative intensities, can be perfectly indexed into the cubic crystalline structure of AuNPs. The crystalite size was calculated from the main diffraction peak (111) using Sherrer's formula:

$$
D=\frac{0,9 \lambda}{\beta \cos \theta}
$$

where $\lambda$ is the $X$-ray wavelength, $\beta$ is the observed full width at half maximum and $\theta$ is the Bragg angle.

Parameters of the crystal cell were estimat- 
ed from the XRD pattern (Table 1). As shown in Table 1, the type of crystal cell is cubic and its parameter (a) equals $4.0732 \AA$. The size of crystallites was found to be $\mathrm{L}=8.1 \pm 0.7 \mathrm{~nm}$.

\section{Immobilization of the enzyme on nanoparticles}

Table 2 demonstrates the quantitative parameters of arginase immobilization on both NPs: efficiency of arginase binding on the surface of AgNPs and AuNPs was 85\% and $86.7 \%$, respectively.

\section{Optical properties of $\mathrm{Ag}$ and $\mathrm{Au}$ nanoparticles}

UV-VIS absorption spectra have been proven to be quite sensitive to the formation of gold and silver colloids because these NPs exhibit intense absorption peaks due to surface Plasmon excitation. ${ }^{17}$ The UV-VIS spectra of both NPs in the $300-700 \mathrm{~nm}$ range are presented in Figure 2. The absorption band in the visible light region and the Plasmon peak at 450 $\mathrm{nm}$ are typical for AgNPs. ${ }^{17-18}$ The maximum absorption for AuNPs was observed at $540 \mathrm{~nm}$, as described by Sun et al. ${ }^{8}$

Figure 3 presents calibration curves for both NPs obtained by spectrophotometry and calculation of NPs concentration on the base of spherical model.$^{3}$ Using slopes values (B) we have obtained the following molar extinctions ( $\varepsilon$ ) for NPs: $1.8 \cdot 10^{6} \mathrm{M}^{-1} \cdot \mathrm{cm}^{-1}$ for AuNPs and $2.5 \cdot 10^{7} \mathrm{M}^{-1} \cdot \mathrm{cm}^{-1}$ for AgNPs.

The total concentration of elemental metals $(\mathrm{Au}, \mathrm{Ag})$ in colloidal solutions was tested gravimetrically. The most difficult challenge was estimation of metallic NPs concentration (in molar equivalents of metal atoms aggregates). For this aim, we used the theoretical model described by Jain et $a l^{3}$ related to cubic or spherical symmetry of the NPs, as well as the linear size of these particles. Approximate calculations were based on a simple geometric base. ${ }^{3}$ Morphological characteristics of AuNPs were obtained by TEM. As shown in Figure $4 \mathrm{~A}$, the average diameter of AuNPs was close to 10 $\mathrm{nm}$, however, after enzyme immobilization, the sizes of nanoparticles increased up to 25$50 \mathrm{~nm}$ (Figure 4B). This phenomenon can be

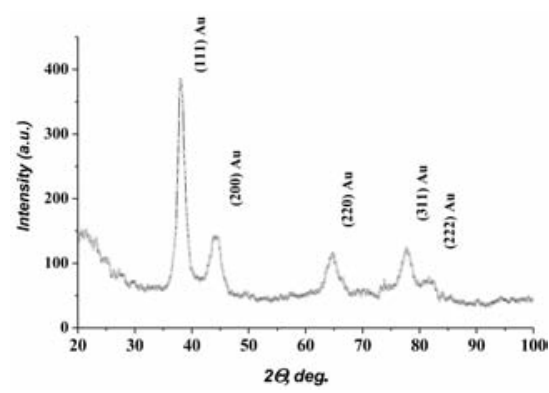

Figure 1. X-ray diffraction pattern of the synthesized AuNPs.
Table 1. Crystal cell parameters.

\begin{tabular}{ll} 
Crystal data & Au $(\mathrm{Cu} \mathrm{K \alpha}$ radiation, $\lambda=1.5418 \AA)$ \\
$\mathrm{M}_{\mathrm{r}}$ & 197 \\
Type of crystal cell & cubic \\
Space group & Fm-3m \\
Parameter of cell & $\mathrm{a}=4.0732 \AA, V=67.58 \AA^{3}$ \\
Scattering angle limits & $2 \theta_{\text {min }}=20.05^{\circ}, 2 \theta_{\text {max }}=100^{\circ}, 2 \theta_{\text {step }}=0.05^{\circ}$ \\
Factors of divergence & $R_{p}=0.044, R_{\mathrm{wp}}=0.057$ \\
$\begin{array}{l}\text { Fractional atomic coordinates and } \\
\text { isotropic or equivalent isotropic } \\
\text { displacement parameters }\left(\AA^{2}\right)\end{array}$ & $(\mathrm{xyz})=(000) ; U_{\text {iso }}^{*} / U_{\text {eq }}\left(0.0377 \cdot(7)^{*}\right)$ \\
\hline
\end{tabular}

Table 2. Activity of the arginase I samples during the immobilization procedure.

\begin{tabular}{|c|c|c|c|c|c|c|}
\hline \multirow[t]{2}{*}{ Parameter } & \multicolumn{2}{|c|}{$\begin{array}{l}\text { Free enzyme } \\
\text { (before } \\
\text { immobilization) }\end{array}$} & \multicolumn{2}{|c|}{$\begin{array}{c}\text { Supernatant } \\
\text { after immobilization } \\
\text { process }\end{array}$} & \multicolumn{2}{|c|}{ Arginase on NP } \\
\hline & $\mathrm{Au}$ & $\mathrm{Ag}$ & $\mathrm{Au}$ & Ag & $\mathrm{Au}$ & $\mathrm{Ag}$ \\
\hline $\mathrm{V}, \mu \mathrm{L}$ & 25 & 25 & 65 & 65 & 50 & 50 \\
\hline Protein concentration, $\mathrm{mg} / \mathrm{mL}$ & 0.50 & 0.50 & 0.30 & 0.15 & ND* & ND \\
\hline Total protein, $\mu \mathrm{g}$ & 12.5 & 12.5 & 20 & 10 & ND & ND \\
\hline Activity, $\mathrm{U} / \mathrm{mL}$ & $47.2 \pm 0.1$ & $47.2 \pm 0.2$ & $2.50 \pm 0.01$ & $3.4 \pm 0.2$ & $20.8 \pm 0.1$ & $20.4 \pm 0.2$ \\
\hline Total activity, U & $1.2 \pm 0.1$ & $1.20 \pm 0.02$ & $0.16 \pm 0.01$ & $0.22 \pm 0.02$ & $1.04 \pm 0.01$ & $1.02 \pm 0.03$ \\
\hline Yield, \% & $=100$ & $=100$ & $13.5 \pm 1.5$ & $18.3 \pm 1.0$ & $86.7 \pm 2.2$ & $85 \pm 1.7$ \\
\hline
\end{tabular}

ND, not determined
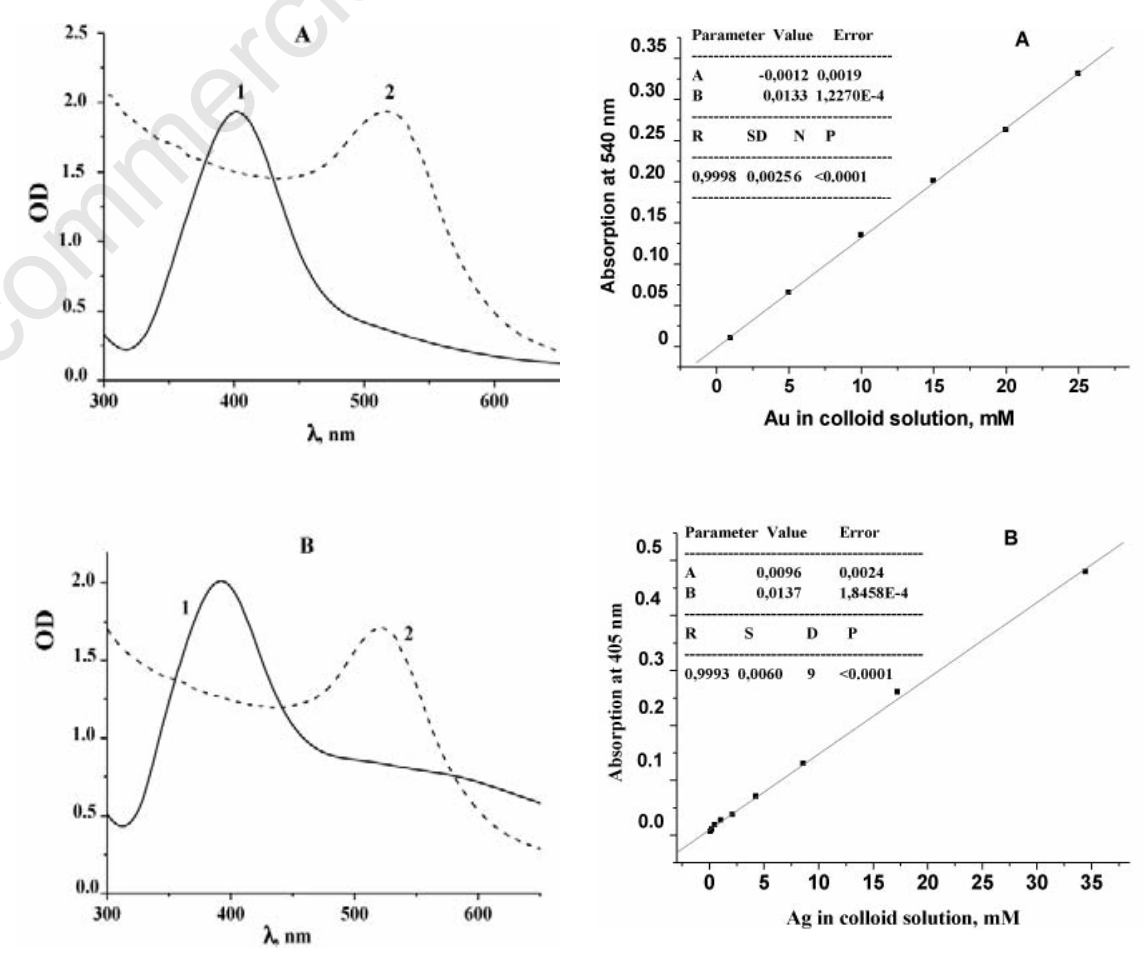

Figure 2. UV-visible spectra of silver (1) and gold (2) nanoparticle solutions. A) before and $B$ ) after arginase immobilization. The total concentrations of the metals in AgNPs and AuNPs are $138 \mathrm{mM}$ and 25 $\mathrm{mM}$, respectively.

Figure 3. The calibration curves for total metal concentrations in NPs. Some statistical data are presented for the parameters of linear regression (coefficients of the equation $Y=A+B X$, where $Y$ - optical density; $X$ - total metal concentration in colloid solution, $\mathrm{mM}$; $\mathrm{R}$ - linear regression coefficient). 
explained by aggregation under the arginase immobilization procedure.

Figure 5 shows the Atomic Force Microscopy (AFM) images of the AuNPs: the average diameter of the particles is about $15 \mathrm{~nm}$. This is larger than the value obtained from the TEM and XRD analysis. This may be attributed to the intrinsic enlarging effect of the microscopic pinpoint to the measured nanoparticles, resulting in the overestimation of dimensions with an AFM. The morphology of AuNPs (Figure 5A) was almost smooth, and their surfaces were homogeneous.

To compare the storage stability of different arginase preparations, enzyme activities of free and both NPs-bound enzyme were determined during several days. As shown in Figure $6 \mathrm{~A}$, only $55 \%$ residual activity was observed in free arginase and arginase-AgNPs after 5 days. However, the residual activity of arginaseAuNPs during the same time period was 95\%, and $40 \%$ after 25 days, demonstrating a considerable enhancement in the enzyme's stability. At the same time, only $20 \%$ arginase activity was observed after 25 days of experiment with arginase-AgNPs. AgNPs are thus less effective nano-carriers for arginase than AuNPs.

The results, presented in Figure $6 \mathrm{~B}$ and $\mathrm{C}$, demonstrate that there is no difference between the $\mathrm{pH}$ optima $(\mathrm{pH} 7.5-9.0)$ and the temperature optima $\left(55-70^{\circ} \mathrm{C}\right)$ for the arginase in solution and immobilized on AuNPs. The thermostability of free arginase and arginase-AuNPs is high too: both preparations kept $100 \%$ and about $15 \%$ of activity after pre-incubation during $15 \mathrm{~min}$ at $70^{\circ} \mathrm{C}$ and $90^{\circ} \mathrm{C}$, respectively.

\section{Discussion}

In the present work, gold and silver nanoparticles were synthesized followed by functionalization of the colloids with 16-mercaptohexadecanoic acid. The size and structure of the NPs were characterized using TEM, AFM and XRD-methods: the size of both nanoparticles was shown to range between 10 and $35 \mathrm{~nm}$.

An effective method for enzyme immobilization on the surface of silver and gold nanoparticles using carbodiimide-pentafluorophenol method was proposed. Recombinant human arginase I was successfully linked on both NPs with a binding efficiency of $85 \%$ for AgNPs and $86.7 \%$ for AuNPs (in the range of added enzyme concentration $0.15-0.5 \mathrm{mg} / \mathrm{mL}$ ). The nano-scale sizes of both arginase-modified colloids were confirmed by scanning electron microscopy. The storage stability of the different arginase preparations during 25 days was shown to increase in the following order: control enzyme in solution, enzyme on AgNPs and enzyme on AuNPs. Thus, the synthesized gold and silver nano-carriers have a stabilizing effect on recombinant human arginase I due to its fixation on the surface of the NPs, preventing enzyme inactivation. ${ }^{9}$ AgNPs are less effective nano-carriers than AuNPs for arginase I, may be due to an inhibitory effect of a theoret-
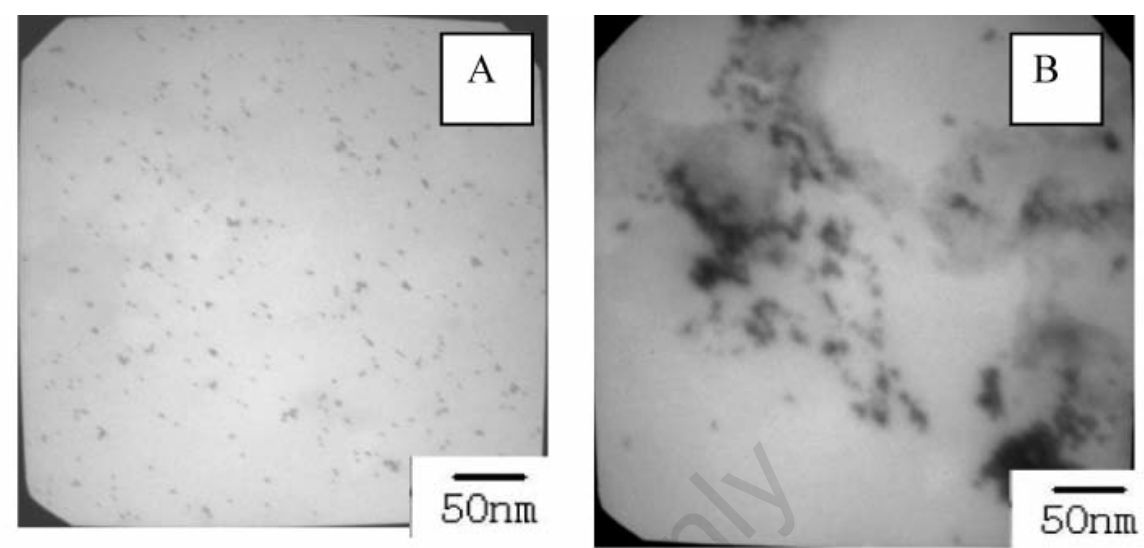

Figure 4. Transmission electron microscopy micrographs of the synthesized AuNPs before (A) and after (B) arginase immobilization.
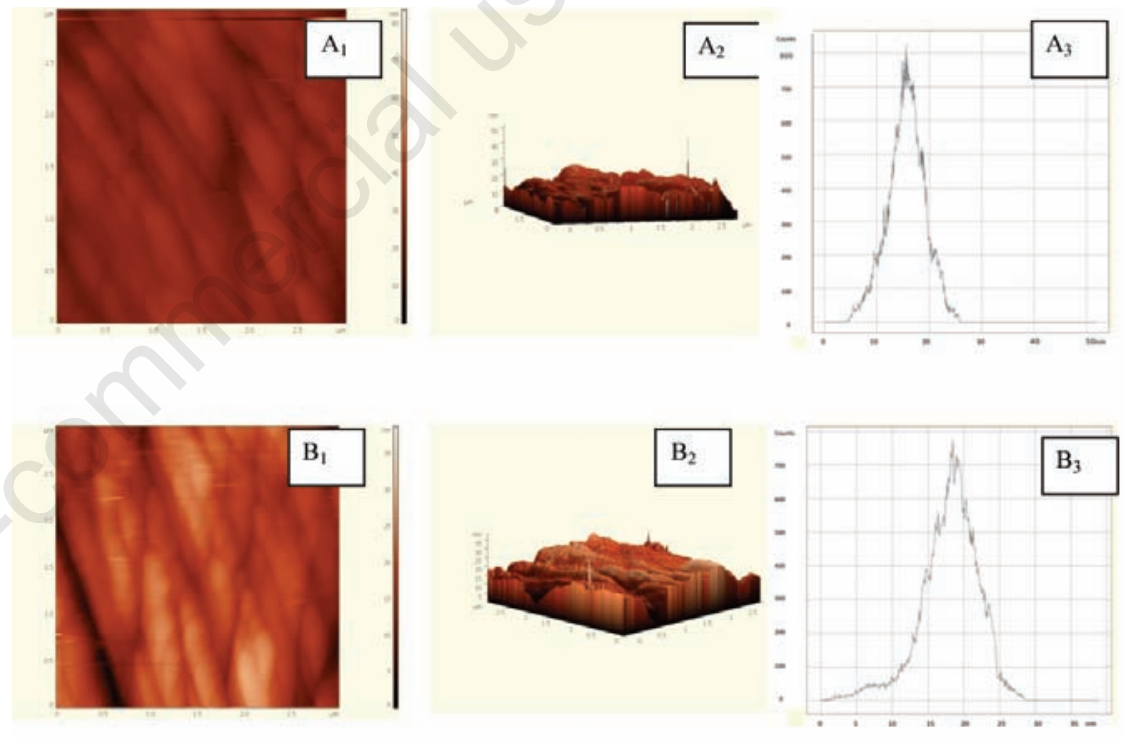

Figure 5. AFM micrographs $(1,2)$ and Gaussian distribution by size (3) of AuNPs before (A) and after immobilization of arginase (B).
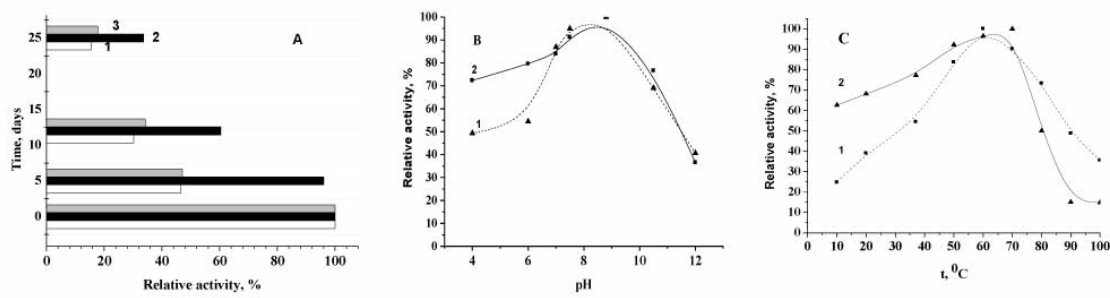

Figure 6. Comparative characteristics of different arginase preparations: in solution (1); immobilized on AuNPs (2) and immobilized on AgNPs (3). A) storage stability; B) pH optima; C) temperature optima. The maximal activities of arginase were taken as $100 \%$ in each case. 
very sensitive and stable biosensors for wide biochemical applications. ${ }^{19-21}$ A high thermostability of immobilized on NPs arginase I preparations and a wide working $\mathrm{pH}$ range of this enzyme allows to hope that it will become a prospective tool for bioanalytical purposes, namely, for arginine monitoring in pharmaceuticals, in food products and in blood.

\section{References}

1. Vu LV, Long NN, Doanh SC, Trung BQ. Preparation of silver nanoparticles by pulse sonoelectrochemical method and studying their characteristics. J Physics: Conference Series 2009;187:1-9.

2. Jennings T, Strouse G. Past, present, and future of gold nanoparticles. Adv Exp Med Biol 2007; 620:34-47.

3. Jain PK, Huang X, El-Sayed IH. El-Sayed MA. Noble metals on the nanoscale: optical and photothermal properties and some applications in imaging, sensing, biology, and medicine. Acc Chem Res 2008;12: 1578-86.

4. ChenY, Preece JA, Palmer RE. Processing and characterization of gold nanoparticles for use in plasmon probe spectroscopy and microscopy of biosystems. Ann N Y Acad Sci 2008;1130:201-6.

5. Bui MP, Baek TJ, Seong GH. Gold nanoparticles aggregation-based highly sensitive DNA detection using atomic force microscopy. Anal Bioanal Chem 2007;388: 1185-90.
6. Baptista P, Pereira E, Eaton P, et al. Gold nanoparticles for the development of clinical diagnosis methods. Anal Bioanal Chem 2008;391:943-50.

7. Vishnyakova EA, Saikova SV, Zharkov SM, et al. Silver Nanoparticles Formation by Glucose Reduction in Aqueous Solutions. Journal of Siberian Federal University. Chemistry 2009;2:48-55.

8. McFarland AD, Haynes CL, Mirkin CA, et al. Color my Nanoworld. J Chem Educ 2004;81:544A.

9. Li D, He Q, Cui Y. Immobilization of glucose oxidase onto gold nanoparticles with enhanced thermostability. Biochem Biophys Res Commun 2007;355:488-93.

10. Niemeyer CM. Nanoparticles, proteins, and Nucleic Acids: Biotechnology meets materials science. Angew Chem Int Ed 2001;40:4128-58.

11. Skrabalak SE, Au L, Lu X, et al. Gold nanocages for cancer detection and treatment. Nanomedicine (Lond.) 2007;2:6578.

12. Radwan SH, Azzazy HM. Gold nanoparticles for molecular diagnostics. Expert Rev Mol Diagn 2009;9:511-24.

13. Alkilany AM, Murphy CJ. Toxicity and cellular uptake of gold nanoparticles: what we have learned so far? J Nanopart Res 2010; 12:2313-33.

14. Wheatley DN. Controlling cancer by restricting arginine availability-argininecatabolizing enzymes as anticancer agents. Anticancer Drugs 2004;15:825-33.

15. Stasyuk NYe, Gayda GZ, Koval'chuk YeP, et al. Human arginase I from the recombi- nant yeast Hansenula polymorpha: isolation and characterization of the enzyme. Ukr Biokim Zh 2010;82:14-21.

16. Marsh WH, Fingerhut B, Miller $\mathrm{H}$. Automated and manual direct methods for the determination of blood urea. Clin Chem 1965;11:624-7.

17. Jain PK, Huang X, El-Sayed IH, El-Sayed MA. Review of some Interesting Surface Plasmon Resonance-Enhanced Properties of Noble Metal Nanoparticles and their Applications to Biosystems. Plasmonics 2007;2:107-18.

18. Gao X, Gu G, Hu Z, et al. A Simple Method for Preparation of Silver Dendrites. Colloid Surface A 2005;254:57-61.

19. Sibirny V, Demkiv O, Sigawi S, et al. Formaldehyde oxidizing enzymes and genetically modified yeast Hansenula polymorpha cells in Monitoring and Removal of Formaldehyde. In: Einschlag FSG, editor. Waste Water - evaluation and management. Rijeka: InTech- Open Access Publisher; 2011. pp. 115-54.

20. Sigawi S, Smutok 0, Demkiv 0, et al. Immobilized formaldehyde-metabolizing enzymes from Hansenula polymorpha for removal and control of airborne formaldehyde. J Biotechnol 2011;153:138-44.

21. Smutok 0, Gayda G, Dmytruk K, et al. Amperometric biosensors for lactate, alcohols and glycerol assays in clinical diagnostics. In: Serra PA, editor. Biosensors Emerging Materials and Applications. Rijeka: InTech- Open Access Publisher; 2011. pp. 401-446. 